\title{
МОДЕЛЮВАННЯ УРОКУ МАТЕМАТИКИ В ПОЧАТКОВІЙ ШКОЛІ З ВИКОРИСТАННЯМ КАРТ ЗНАНЬ
}

\begin{abstract}
Анотація. У статті дано визначення основним дефініціям: вчитель початкової школи, математика початкової школи, урок математики початкової школи, моделювання, карти знань, ІКТ, онлайн ресурси для створення карт знань. Проаналізовано як вітчизняний, так і зарубіжний досвід застосування карт знань на уроках математики; обгрунтовано методику організащійно-методичних основ моделювання уроку математики з використанням карт знань; відібрано сучасні онлайн ресурси для створення карт знань. Розглядаються особливості моделювання уроку математики в початковій школі за допомогою карт знань та обірунтовується необхідність використання нових підходів у процесі навчання математики в початковій школі. Описано програмні засоби для створення інтелектуальних карт, зокрема Mindomo, Соggle, Lucidchart, Canva, Draw.io, які доцільно застосовувати для створення карт знань на уроках математики в початковій школі, визначено їхні переваги та наведено 10 простих правил створення карт. Відображено практичне застосування карт знань на уроках математики в початковій школі.
\end{abstract}

Ключові слова: вчитель початкової школи, математика початкової школи, урок математики початкової школи, моделювання, карти знань, ІКТ, онлайн ресурси для створення карт знань.

\section{Rudenko Nina, Kravchuk Anna, Shyrokov Denys} Borys Grinchenko Kyiv University

\section{MATHEMATICS LESSON MODELING IN A PRIMARY SCHOOL USING MIND MAPS}

Summary. Due to the globalization changes taking place in the world at the beginning of the XXI century, it can be stated that in the most developed countries of the world there is an intensive introduction of information and communications technologies in all spheres of human life, including education. Globalization and technological changes, which have accelerated over the past fifteen years, have created a new world economy based on technology, information-driven and knowledge-driven approaches. Ukraine does not stand aside from these changes, so ICT has entered the educational process of all levels of education in Ukraine. The extensive use of modern information and communications technologies in the educational process provides an opportunity to reveal the significant scientific potential of studying mathematics, to gain the knowledge necessary for many modern professions related to new information and production technologies. In this regard, the primary school also can not remain just an institution for transferring information from a teacher to a student during the first four years of studies, but on the contrary, it is the primary school where the teacher must apply organizational and methodological foundations which help students to learn, acquire knowledge and skills that make lifelong learning possible. And the combination of ICT with the use of mind maps in mathematics lessons in a primary school facilitates the process of acquiring knowledge and creates a comfortable learning environment both for teachers and primary school students. The article defines the main definitions: primary school teacher, primary school mathematics, primary school mathematics lesson, modeling, mind maps, ICT, online resources for creating mind maps. Both domestic and foreign experience in the use of mind maps in mathematics lessons is analyzed; the technique of modeling a mathematics lesson with the use of mind maps is substantiated; modern online resources for creating mind maps are selected. The peculiarities of modeling a mathematics lesson in a primary school with the use of mind maps are considered and the necessity of using new approaches in the process of teaching mathematics in a primary school is substantiated. Software tools for creating mind maps, including Mindomo, Coggle, Lucidchart, Canva, Draw.io, which are useful to create mind maps in primary school mathematics lessons, are described, their benefits are identified, and 10 simple rules for creating maps are given. The practical application of mind maps in mathematics lessons in a primary school is revealed.

Keywords: primary school teacher, primary school mathematics, primary school mathematics lesson, modeling, mind maps, ICT, online resources for creating mind maps.

$\Pi$ остановка проблеми. У зв'язку з глобалізаційними змінами, що відбуваються у світі на початку XXI століття можна констатувати такий фракт, що у найрозвиненіших країнах світу здійснюється інтенсивне впровадження інформаційно-комунікаційних технологій у всіх сdpepax людського буття, зокрема і в освіті. Глобалізація та технологічні процеси змін, які пришвидшились за останні п'ятнадцять років, створили нову світову економіку, що базуеться на технологіях, підживлюеться інфрормацією та керується знаннями. Україна не стоїть осторонь цих змін, тому IКT ввійшли в навчальний процес всіх ланок освіти України. Широке використання сучасних інформащійно-комунікаційних технологій у навчальному процесі дає можливість розкрити значний науковий потенціал вивчення математики, сформувати знання, які лежать в основі багатьох сучасних професій, пов'язаних з новими інформаційними та виробничими технологіями.

У зв'язку 3 цим початкова школа теж не може залишатися простим місцем для передачі інформації від вчителя до учня протягом перших чотирьох років навчання, а навпаки, саме в початковій школі вчитель має володіти організаційно-методичними основами, за допомогою яким може навчити учнів вчитися, набувати знань та навичок, які роблять можливим безпе- 
рервне навчання протягом усього майбутнього життя. А поєднання ІКТ з використанням карт знань на уроках математики в початковій школі полегшує процес здобування знань і створює комфортні умови навчання як для вчителя, так для здобувачів початкової освіти.

Аналіз останніх досліджень і публікацій. Вивченням форм та методів навчання займалися багато вчених-педагогів, зокрема В. Беспалько, I. Васильев, Р. Гуревич, Г. Джоунс, К. Кнаппер, I. Лернер, В. Ортинський, І. Підласий, Е. Саймон, Л. Товажнянський та інші. Методу моделювання присвячені педагогічні дослідження вітчизняних, так і зарубіжних науковців: Ю. Бабанського, В. Безпалька, Р. Гуревича, О. Манакової, Н. Морзе, В. Мороз, В. Сластьоніна та інших. Методищі вивчення математики в початковій школі присвячені роботи Л. Коваль, С. Логачевської, О. Онопрієнко, С. Скворцової та ін. Проблемам застосування інфрормаційно-комунікаційних технологій та особливостям використання Інтернету в навчальному процесі присвячені дослідження вчених: В. Бикова, Р. Гуревича, Г. Кедровича, М. Кадемії, М. Козяра, Н. Морзе, Н. Опушко, С. Сисоєвої та ін. Впровадженню інтерактивного навчання приділяли увагу такі науковці: Н. Білецька, С. Гончаров, С. Грабовська, Н. Козлова, О. Комар, В.А. Петрук, О. Пометун, Н. Руденко, О. Січкарук та інші. Методикам навчання та моделювання сучасного уроку математики в початковій школі за допомогою ІКТ присвячені роботи: Ю. Мажуги, Н. Руденко, Л. Романенко та інших. Зарубіжні вчені, які досліджували використання карт знань: Buzan B., Buzan T., Barra W. Kuswanto H., Wilujeng I.; використання карти знань на урощі математики досліджували: Polat O. Tunc A., Yvuz A.; вивченням інструментарію та моделювання карт знань, займалися такі науковці: Lee H., Messom C., Ong T.; вивчення застосування карт знань з психологічної сторони займались: Mahasneh A., Santiago H.

Виділення невирішених раніше частин загальної проблеми. У зв'язку з викликами, що створила пандемія COVID-19 та впровадженням дистанщійного навчання в $33 \mathrm{CO}$ потребуе нових методів і організація навчального процесу в початковій школі. Вчителям необхідно навчитися якісно проводити он-лайн уроки за допомогою ІКТ ресурсів, зокрема моделюванню уроків за допомогою карт знань, а учням початкової школи потрібно оволодіти вміннями вчитися самостійно. Успішне моделювання уроків математики в початковій школі за допомогою карт знань дозволяе вирішити проблеми впровадження дистанщійної освіти в Україні, що сприятиме підвищенню якості знань учнів початкової школи.

Мета статті. Головною метою цієї роботи $€$ обгрунтування педагогічної доцільності й дидактичної цінності застосування методики створення та використання карт знань на уроках математики в початковій школі. Завданням џіеі статті є: здійснити теоретичний аналіз наукової проблеми та визначити основні поняття дослідження; проаналізувати наукову літературу 3 організаційно-методичних основ моделювання уроку математики з використанням карт знань; відібрати програмні засоби, які можна використовувати для створення карт знань на сучасний урок математики; розробити модель сучасного уроку математики з використанням карт знань.

Виклад основного матеріалу. Коротко означимо основні дефініції нашої статті, а саме урок математики, вчитель початкової школи, моделювання, карти знань, IКТ, онлайн ресурси для створення карт знань.

Вчитель початкової школи - педагог, який забезпечуе навчально-пізнавальну діяльність, виховання та розвиток учнів початкової школи. Він організовує навчальний процес для учнів початкових класів відповідно до навчальних програм і плану роботи, розроблених для конкретного навчального закладу [4].

Математика початкової школи - математична освітня галузь, метою навчання якої $€$ різнобічний розвиток особистості здобувача початкової освіти та їі світоглядних орієнтащій засобами математичної діяльності, фрормування математичної й інших ключових компетентностей, необхідних їй для життя та продовження навчання. Урок є основною - формою навчального процесу вивчення математики в початковій школі.

Урок математики в початковій школі-заняття 3 групою учнів постійного складу, одного рівня підготовки впродовж чотирьох років відповідно до вибраної навчальним закладом Типової програми Нової української школи (О. Савченко або Р. Шияна) та підручника "Математика», який відповідає обраній програмі.

Моделювання (наукове моделювання) (scientific modelling, simulation) - це особливий пізнавальний процес, метод теоретичного та практичного опосередкованого пізнання об'єкту, при якому вибирається або створюеться схожий із ним допоміжний об'єкт-замісник (модель), досліджується, а здобута інформащію переноситься на реальний предмет вивчення. Моделювання використовується тоді, коли безпосереднє вивчення об'єктів 3 деяких причин неможливе [3].

В нашому випадку нас цікавить моделювання педагогічного процесу, в даному випадку уроку математики в початковій школі.

Практична цінність педагогічної моделі полягає в тому, що вона визначається ступенем ïi відповідності ключовим об'ектам що вивчаються, крім того, на їі цінність впливають такі характеристики, як наочність, визначеність, об'ективність [2, с. 154].

На сучасному етапі розвитку пізнання особливо велика роль відводиться моделюванню за допомогою ІКТ.

Інбборлаиійно-колунікаиійні технологї (ІКТ, від англ. Information and communications technology, ICT) - використовується як синонім до інформаційних технологій (IT), IКТ це загальний термін, який підкреслює роль уніфрікованих технологій та інтеграцію телекомунікацій (теледронних ліній та бездротових з'єднань), комп'ютерів, підпрограмного забезпечення, програмного забезпечення, накопичувальних та аудіовізуальних систем, які дозволяють користувачам створювати, одержувати доступ, зберігати, передавати та змінювати інформацію. Вираз вперше було використано в 1997 році у доповіді Денніса Стівенсона для уряду Великої Британії, який посприяв створенню нового Національного навчального плану Великої Британії в 2000 році [1]. 
Нині помітно зросла кількість досліджень, предметом яких стало використання інформаційно-комунікаційних технологій у навчальному процесі. Цій темі в Україні присвячені дослідження таких науковців, як В. Биков, Я. Булахова, О. Бондаренко, В. Заболотний, Г. Козлакова, О. Міщенко, О. Пінчук, О. Шестопал та інші.

Карти знань - сукупність діаграм і схем, що в наочному вигляді демонструють думки, тези, пов'язані одна з одною та об'єднані загальною ідеєю.

Одним зі способів підвищення ефективності навчального процесу з урахуванням особливостей мислення сучасного учня $є$ включення інтерактивних технік, зокрема застосування ментальних карт, які допомагають знизити інформаційне навантаження, відновити навички фокусування уваги, стимулювати основні когнітивні процеси, формувати стійкі інтелектуальні вміння, комунікативну та інтелектуальну компетентність. В основі ментальної карти лежить принцип когнітивної візуалізації, згідно з яким візуалізація виконуе не тільки ілюстративну функцію, а й безпосередньо стимулюе інтелектуальний процес отримання знань, забезпечуючи активізацію пізнавальних операцій.

Отже, використання карт знань в навчальному процесі дає такі можливості: поліпшення пам'яті, нагадування фоктів та образів; фокусування уваги; генерування ідей; надихання на пошук рішень; аналіз та розуміння теми; запам'ятовування матеріалу уроку; організація взаемодії при груповій роботі в класі.

Залежно від обсягу або застосування Т. Бьюзен (ввів поняття «карта думок») розрізняе такі типи ментальних карт рис. 1.

За допомогою ментальної карти інтерактивного уроку зручно створювати конспект уроку математики, особливо це важливо для учителів початкової школи, для цікавої організащії взаемодії всіх учнів на уроці, оскільки інформація запам'ятовуеться, якщо вона представлена у структурованому вигляді, та ще й містить графічні зображення та відео, інтерактивні аркуші Live Worksheets тощо. Для створення інтелект карти необхідно обрати ресурс, відповідне програмне забезпечення. На даний час існуе більше сотні засобів, які мають свої переваги та недоліки. Для ефективного користування будь-яким інструментом варто почитати інструкцію. Особливо варто ознайомитись вчителям, які тільки починають пізнавати техніку Mind Mapping.

Отже, сфборлулюемо 10 простих правил створення карт:

1. Починаємо з центральної ідеї посередині чистого аркушу, використовуючи малюнок $\mathrm{i}$ хоча б 3 кольори.

2. Використовуємо картинки, символи, коди і заповнюемо ними весь вільний простір.

3. Вибираємо ключові слова і друкованим текстом наносимо на гілки, використовуючи верхній та нижній регістр.

4. Кожен елемент (слово/картинка) повинен мати власну гілку.

5. Лінії повинні бути з'єднані, починаючи від центральної ідеї. Центральні лінії товстіші, органічні і текучі. Всі наступні гілки стаючи тоншими в залежності від радіального розходження від центру.

6. Робимо лінії такої ж довжини, як і слово/ картинка.

7. Використовуемо кольори на власний розсуд і на всій карті пам'яті.

8. Розробляемо свій особистий стиль майнд меппінгу.

9. Використовуємо акценти і показуємо асоціації на своїй карті пам’яті.

10. Зберігаємо ясність інтелектуальної карти, використовуючи радіальну ієрархію в цифровому порядку, або охоплюючи всі гілки.

В роботі Н. Руденко були описані е-ресурси FreeMind, Bubbl.us, MindMeister [4, c. 100]. Нами було проведено опитування студентів, щодо сучасного стану використання карт знань. На основі нього було відібрано онлайн ресурси для створення карт знань, зокрема Mindomo, Coggle, Lucidchart, Canva, Draw.io та інші. Розглянемо переваги та недоліки цих ресурсів , якими зручно користуватися для підготовки вчителів початкової школи до проведення уроків математики рис. 2.

$\mathrm{y}$ процесі навчання математики в початковій школі застосування ментальних карт представлено рис. 3.

Наведемо приклад уроку математики для 1 класу на тему «Знайомимося 3 одиницею вимірювання довжини "метр»"» (за підручником О. Онопріенко та С. Скворцової) із застосуванням

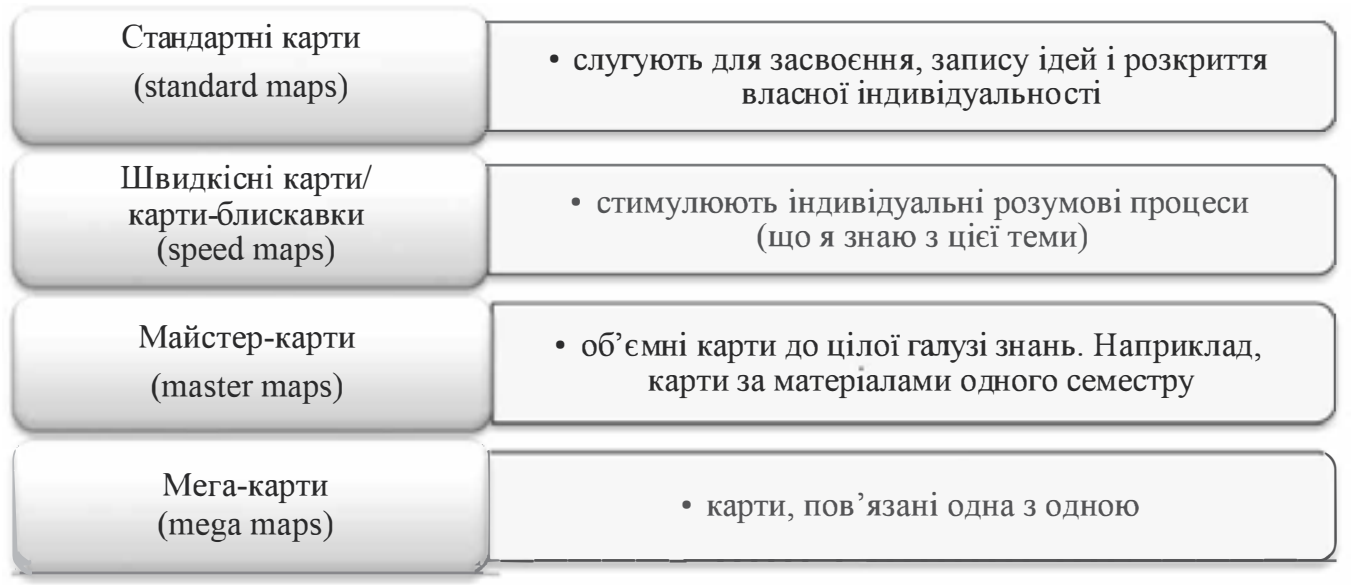

Рис. 1. Класифікація типів ментальних карт 


\section{Опис переваг та недоліків обраних ресурсів}
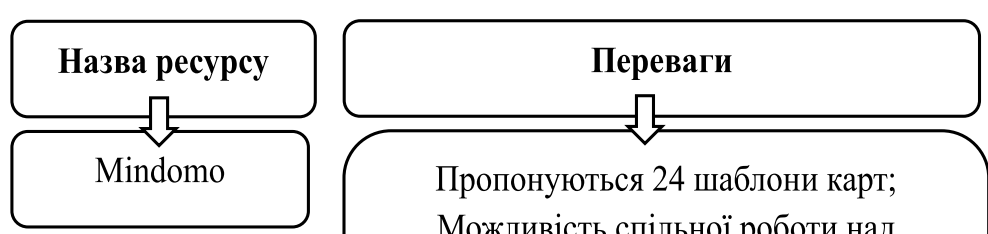

Пропонуються 24 шаблони карт;

Можливість спільної роботи над

картою декількома користувачами.

Додаються аудіо та відео-

записи. зображення. гіперпосилання.

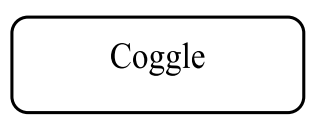

Експорт в формат PNG, PDF; Можлива спільна робота над картою за чатом та коментарями; Синхронізація з Google Диском; Доступна галерея чужих карт; Більше 1600 іконок
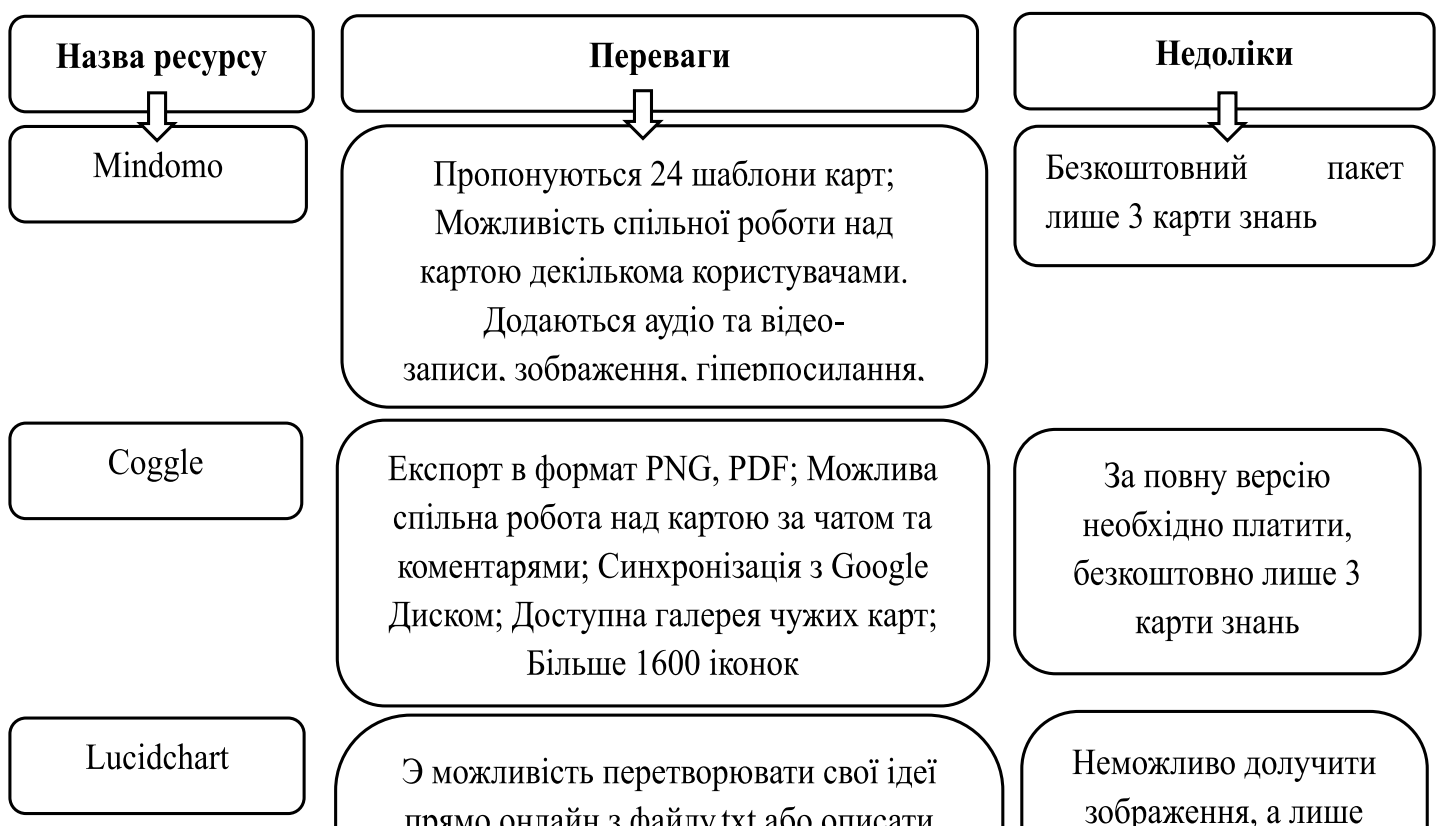

Э можливість перетворювати свої ідеї прямо онлайн з файлу.txt або описати структуру безпосередньо в Lucidchart; підтримує експорт карти в формати:PDF,JPEG i PNG. Гілки карти легко згортати, а структуру можна скласти автоматично. Має шаблони 3 ментальних карт

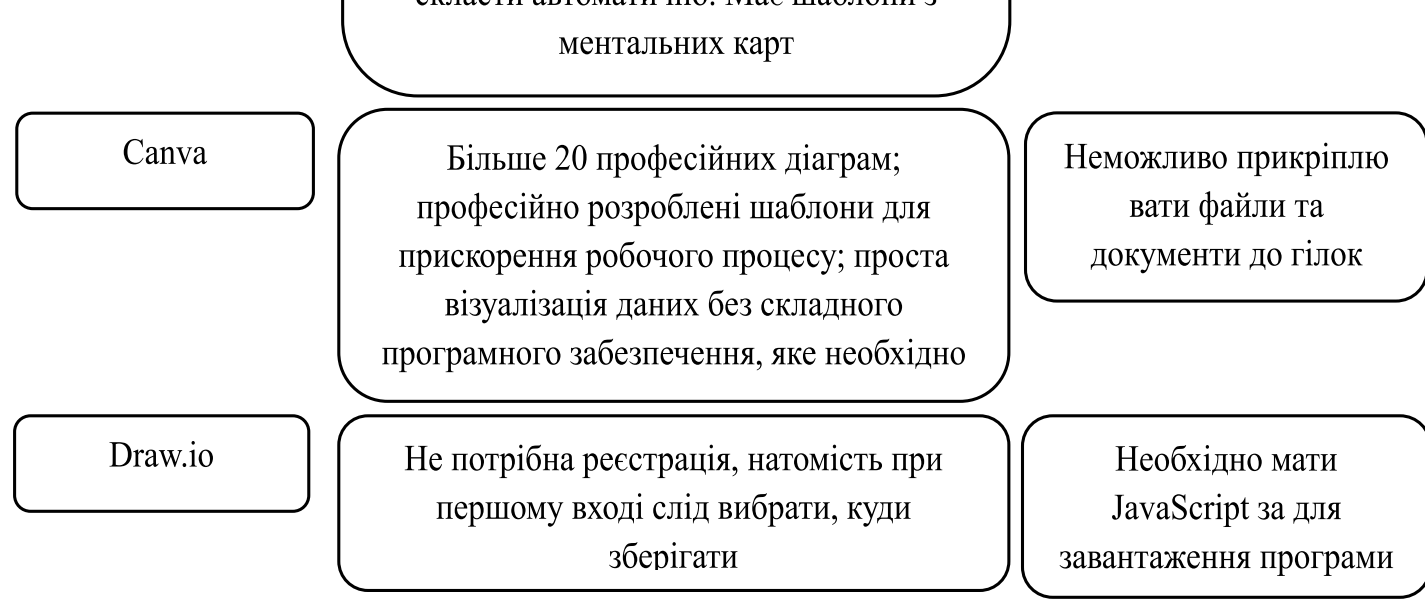

Рис. 2. Опис переваг та недоліків обраних ресурсів

Джерело: розроблено авторами

Під час підготовки матеріалу уроку

Для ефективного сприйняття, розуміння та запам'ятовування інформації

У процесі самостійної роботи; як засіб контролю та оцінювання знань

Для вивчення нового матеріалу, його закріплення та узагальнення на всіх типах уроків

Рис. 3. Застосування ментальних карт на уроках математики 
e-pecypcy MindMaps [6]. Цей ресурс має свої переваги для використання на різних типах уроків математики в початковій школі. На уроці засвоєння нових знань, умінь та навичок карти знань забезпечують учню краще розуміння матеріалу, що вивчається, запам'ятовування необхідних відомостей у логічній та образній формах; створюе позитивну мотивацію. На уроці застосування знань, вмінь та навичок MindMaps дозволяють організувати індивідуальну, групову навчальну діяльність на основі диференційного підходу, самостійну роботу в поєднанні 3 іншими освітніми технологіями. А саме на уроці перевірки, оцінювання та корекції знань, вмінь та навичок вдало використовувати MindMaps для перевірки засвоєння теми, самостійної та групової роботи в класі, запропонувати заповнити інтелект карту по пам'яті та розмалювати її, створити свою інтелект карту, ця робота буде сприяти розвитку особистісних якостей учнів, змушуе їх мислити по-новому, творчо та невимушено, максимально використовуючи обидві півкулі головного мозку, роблячи процеси навчання і учіння більш цікавими та плідними.

Зразок уроку математики змодельований авторами за допомогою MindMaps поданий за посилання https://mm.tt/1858639352?t=3deSm2QEaX. Такий урок математики, змодельований за допомогою MindMaps, зручно використовувати і під час дистанційного навчання, коли вчитель ра- зом з учнями рухаеться по карті під час уроку, відкриває потрібні завдання, відео, інтерактивні аркуші Live Worksheets із індивідуальними завданнями тощо.

Висновки та пропозиції. За концепцією Нової української школи, передбачено активне впровадження компетентнісного підходу, що зумовлюе використання інтелект карт на уроках математики в початковій школі дозволяе оптимізувати навчальний процес, активізувати увагу учнів до роботи на уроці, розвивати їхнє мислення, полегшує перехід від наочнообразного до словесно-логічного, понятійного мислення; сприяе підвищенню якості знань здобувачів початкової освіти, інтересу до вивчення математики, розумінню основних понять курсу математики початкової школи. Забезпечити якісну підготовку здобувачів початкової освіти до життя може лише творчий учитель, здатний до проведення уроків математики в яких обов'язково мають бути присутні навички створювати плани конспекти із застосуванням ментальних карт, використовуючи програмні ресурси (зокрема Mindomo, Coggle, Lusidchart, Canva, Draw.io та інші). Використання ментальних карт відкриває великий діапазон для урізноманітнення завдань для організації роботи на уроці математики в сучасній початковій школі. Застосування карт знань з інтерактивними аркушами Live Worksheets потребуе подальшого дослідження.

\section{Список літератури:}

1. Інформаційно-комунікаційні технології. URL: http://surl.li/xfth

2. Козіброда С.В., Цідило I.M. Модель системи підготовки майбутніх інженерів-педагогів у галузі комп'ютерних технологій до вивчення та застосування онтологій компютерних систем. Наукові записки РДГУ. 2017. Випуск 16(59). С. 154-158.

3. Наукове моделювання. URL: http://surl.li/xftm

4. Професійний стандарт «Вчитель початкових класів закладу загальної середньої освіти». URL: https://www.msp.gov.ua/files/News/20180815/20180815.pdf

5. Руденко Н.M. Особливості підготовки майбутніх учителів початкової школи до застосування ментальних карт на уроках математики. Освітологічний дискурс. 2020. № 2(29). С. 92-104.

6. Скворцова С.О., Онопрієнко О.В. Математика : підручник для 1 класу закладів загальної середньої освіти. Київ : Ранок, 2018. 150 с.

\section{References:}

1. Information and communication technologies. Available at: http://surl.li/xfth (accessed 05 June 2021).

2. Kozibroda, S.V., \& Tsidilo, I.M. (2017) Model of the system of preparation of future engineers-teachers in the field of computer technologies for studying and application of ontologies of computer systems. Scientific notes of RDGU, 16(59), 154-158.

3. Scientific modeling. Available at: http://surl.li/xftm (accessed 10 June 2021).

4. Professional standard "Primary school teacher of general secondary education". Available at: https://www.msp.gov.ua/ files/News/20180815/20180815.pdf (accessed 15 June 2021).

5. Rudenko, N.M. (2020) Peculiarities of preparation of future primary school teachers for the use of mental maps in mathematics lessons. Educational discourse, 2(29), 92-104.

6. Skvortsova, S.O., \& Onoprienko, O.V. (2018) "Mathematics" textbook for 1 class of general secondary education. Kyiv: Ranok. 